\title{
Family Capitals, Livelihood Strategies, and Family Well-Being of Plantation Worker
}

\author{
Nurul Salimah* \\ Department of Family and Consumer Sciences, \\ Faculty of Human Ecology, \\ Bogor Agricultural University
}

\author{
Istiqlaliyah Muflikhati \\ Department of Family and Consumer Sciences, \\ Faculty of Human Ecology, \\ Bogor Agricultural University
}

*Corresponding author: nuruls919@gmail.com

\begin{abstract}
This study aimed to analyze the influence of family characteristics, family capitals, and livelihood strategies on family well-being. The sample of this study was family with wife who worked as a tea picker in Purwabakti Village, Pamijahan Sub-District, Bogor Regency. There were 100 families chosen randomly in this study. Family well-being was observed based on indicators defined by National Population and Family Planning Board (NPFPB) and Statistics Indonesia (SI). The analysis used in this study were descriptive analyses, independent sample T-test, and logistic regression. The result showed that husband age and family size negatively affected on the family well-being. Physical capital and financial capital positively affected on the family well-being. Meanwhile, livelihood strategy did not significantly affect on the family well-being.
\end{abstract}

Keywords: family capitals, family well-being, livelihood strategies

\begin{abstract}
Abstrak. Kajian ini bertujuan untuk menganalisis pengaruh karakteristik keluarga, kepemilikan modal keluarga, dan strategi nafkah terhadap kesejahteraan keluarga. Sampel kajian ini adalah keluarga dengan istri yang bekerja sebagai buruh pemetik teh di Desa Purwabakti, Kecamatan Pamijahan, Kabupaten Bogor. Seramai 100 keluarga dipilih secara acak dalam kajian ini. Kesejahteraan keluarga diukur dengan menggunakan indikator Badan Kependudukan dan Keluarga Berencana (BKKBN) dan Badan Pusat Statistik (BPS). Analisis yang digunakan dalam kajian ini adalah analisis deskriptif, uji beda independent sample T-test dan uji regresi logistik. Hasil kajian menunjukkan umur suami dan ukuran keluarga berpengaruh negatif signifikan terhadap kesejahteraan keluarga. Modal fisik dan modal finansial berpengaruh positif signifikan terhadap kesejahteraan keluarga. Sementara itu, strategi nafkah tidak berpengaruh signifikan terhadap kesejahteraan keluarga.
\end{abstract}

Kata kunci : kesejahteraan keluarga, modal keluarga, strategi nafkah 


\section{Introduction}

The plantation worker is one of labor groups with low income. The income based on wholesale system causes the uncertainty of family income of plantation worker. The study of Firdaus (2008) showed that more than half samples had got income which was below the City Minimum Wage (CMW) with the average of family income per capita was Rp200.156. According to Sunarti (2008), most workers were still categorized as poor although they had worked full time even overtime. The resilience toward poverty often demands the plantation worker to have livelihood strategy so that their family will survive. Livelihood strategy is an optional aspect of several livelihood sources available in the society (Widodo, 2011). The study of Widanto et. al (2010) showed that livelihood strategy was applied by the plantation workers differently depended on capital owned. Ellis (1998) revealed that the family capital consists of physical, financial, human, natural, and social capitals. Livelihood strategy was divided into three groups: agricultural intensification-extensification, livelihood diversification, and migration (Scoones, 1998). Ellis (1998) revealed that livelihood strategy is applied by family not only to survive but also to increase the life standard. The purpose of livelihood strategy is to obtain well-being encompasses food and income safety (Ellis, Kutengule, and Nyasulu, 2002).

Along with the purpose of livelihood strategy, the family has purpose to attain well-being in running their lives. Sunarti (2013) suggested that well-being is a level of basic need attainment and family developmental need. The effort of family in attaining well-being is conducted through managing the family capital optimally. The study of Firdaus (2008) also showed that the well-being of most women plantation worker families was categorized as moderate. The factors influencing the objective family wellbeing are husband age, family size, family income (Elmanora, Muflikhati, and Alfiasari, 2012), and economic pressure (Sunarti, 2012). The study of livelihood strategy and well-being of plantation worker family are important to be conducted to reveal the effort of plantation worker families in maintaining their life and attaining well-being.

The previous study of livelihood strategy and well-being emphasized the most on livelihood strategy and well-being of poor citizen in urban and rural area (Pramudita, 2014), of horticultural farmer (Harianto, 2013; Widiyanto, Suwarto, and Setyowati, 2010), and of coastal society (Widodo, 2011). This study emphasizes on livelihood strategy of plantation worker family with undetermined income due to wholesale system. Based on those facts, the purpose of this study was: (1) to identify the capital ownership of plantation worker family; (2) to identify the livelihood strategy of plantation worker family; (3) to identify the well-being of plantation worker family; (4) to analyze the influence of family characteristics, capital ownership, and livelihood strategy on the well-being of plantation worker family.

\section{Method}

\section{Participants}

This study used the cross-sectional design study. The location was chosen purposively that was in Purwabakti Village, Pamijahan Sub-District, Bogor Regency. The sub-district chosen had the highest percentage of plantation worker family based on data from the Statistics Indonesia (2010). The study planning was conducted in five 
months started from January until May 2015 while the data collecting was conducted on April 2015. The sample criteria of this study was a family with the wife who was a plantation worker in PTPN VIII Cianten Tea Plantation, Purwabakti Village, Pamijahan Sub-District, Bogor Regency. The wife was chosen as the respondents. As many as 100 families were chosen randomly.

\section{Measures}

The primary data collected was family characteristics, family capital ownership, livelihood strategy, and objective family well-being. The data was collected by interview using questionnaire. The family characteristics consisted of the age of husband and wife, length of education of husband and wife, family income, family size, and occupation of husband and wife. The age of husband and wife was categorized into three categories: early adulthood (age 20-24), middle adulthood (age 41-65), and late adulthood (age over 65) (Papalia, Olds, and Feldman, 2009). The length of education of husband and wife was categorized into not school (0 year), elementary school (1-6 years), junior high school (7-9 years). The family income was the monthly family income per capita. The family size was assessed based on number of family members and was categorized into small ( $\leq 4$ people), middle (5-6 people), and big ( $\geq 7$ people) (NPFPB, 2005).

The family capital ownership was assessed based on the concept of capital ownership by Ellis (1998). There were 54 items which were divided into five indicators: human capital (3 items), physical capital (28 items), financial capital (5 items), social capital (13 items), and natural capital (5 items). The items were measured by Guttman scale $(1=$ Yes, $0=$ No) and the obtained score ranged from 0 until 54 . The obtained score was indexed and categorized into three groups: (1) low (0-33.3); (2) moderate (33.466.7); and (3) high (66.8-100).

The livelihood strategy was assessed by modified questionnaire of livelihood strategy by Scoones (1998), contained by agricultural intensification-extensification, livelihood diversification, and migration. There were 13 items measured by Guttman scale $(1=$ Yes, $0=\mathrm{No})$ with the obtained score ranged from 0 until 13 . The obtained score was also indexed and categorized into three groups: (1) low (0-33.3); (2) moderate (33.4-66.7); and (3) high (66.8-100).

The family well-being was assessed by the indicator of National Population and Family Planning Board (NPFPB) and poverty line by Statistics Indonesia (SI). The NPFPB indicator was contained by 21 items with score ranged from 0 until 1 (1=yes, $0=$ no). NPFPB classify the family well-being into five stages: Pre-Prosperous, Prosperous I, Prosperous II, Prosperous III, and Prosperous III Plus. Based on those groups, the family is categorized into: (1) poor, (pre-prosperous and prosperous I); and (2) non poor (prosperous II, prosperous III, and prosperous III Plus) (Elmanora, Muflikhati, and Alfiasari, 2012). Based on the poverty line of Bogor Regency by Statistics Indonesia (2013), the family is categorized into: (1) poor family (income below Rp271.970/capita/month); and (2) non poor family (income above Rp271.970/capita/month).

\section{Analysis}

The data was analyzed by descriptive analysis that was used to describe the family characteristics, family capital ownership, livelihood strategy, and family well- 
being. Logistic regression analysis was used to analyze the influence of characteristics, capital ownership, and livelihood strategy on family well-being based on indicator from NPFPB.

\section{Result}

\section{Family Characteristics}

The result showed that the mean age of husband was about 47 year old and of wife was 43 years old. Therefore, they were categorized as middle adulthood (age 4165) (Papalia, Olds, and Feldman, 2009) and in productive age as well (age 15-64) (Statistics Indonesia, 2012). The length of education of husband on average (5 years) is higher than wife (4 years). Yadollahi et al. (2009) stated that education level is one of the factors which determines economic status and occupation of oneself. The mean of family size was 3.55 which was categorized as moderate (NPFPB, 1995). Meanwhile, the average of family income per capita was Rp507.475.

Table 1 Family characteristic

\begin{tabular}{lccccc}
\hline Variable & Minimum & Maximum & Mean & \pm & SD \\
\hline Husband age (year) & 29 & 80 & 47.10 & \pm & 11.52 \\
Wife age (year) & 25 & 64 & 42.86 & \pm & 8.11 \\
Length of education of husband (year) & 0 & 9 & 5.06 & \pm & 1.87 \\
Length of education of wife (year) & 0 & 9 & 3.95 & \pm & 2.31 \\
Family size (person) & 2 & 7 & 3.55 & \pm & 1.13 \\
Income per capita (IDR) & 91.666 & 1.625 .000 & 507.475 & \pm & 372.227 \\
\hline
\end{tabular}

\section{Family Capital}

The human capital is a capacity owned by every human being in a certain period of time that influences sources management and its utilization in the future (Muflikhati et al., 2010). This study assessed human capital based on education level of the family, family enrollment in non-formal education (training/course), skill owned by the family, family health condition, and wife employment status. The result showed that family ownership on human capital was categorized as low with the average of 32.22.

The physical capital in this study was seen from family personal capital ownership (vehicle, electronic devices, livestock, land, and farming tools) that support the family in working and it was money valued. The result of this study showed that the family ownership on physical capital was categorized moderate with the average was 36.30. Meanwhile, the financial capital in this study referred to the ownership on cash, saving, debt, and insurance. The result showed that family ownership on financial capital was categorized as moderate with the average of 41.17 .

The social capital is the social network and institution in which an individual participates and obtains the support for hislife (Chambers and Conway, 1991). In this study, the social capital encompassed the family involvement in organization or institution, assitantance and trust ownership from others, network and relationship quality of family with others. The result showed that the family ownership on social capital was categorized as high with the average of 80.61 .

The natural capital in this study was assessed from the natural sources availability which was not owned by the family but was accessible freely for their lives even for increasing family income. The natural capital in this study contained by farm, 
forest, river, and paddy field. The result showed that the family access on natural capital was categorized as moderate with the average of 46.74 .

Table 2 The average of family capital ownership

\begin{tabular}{lccccc}
\hline Variable & Minimum & Maximum & Mean & \pm & SD \\
\hline Human capital & 16.67 & 66.67 & 32.41 & \pm & 8.51 \\
Physical capital & 14.28 & 60.71 & 35.11 & \pm & 8.44 \\
Financial capital & 25.00 & 83.30 & 38.44 & \pm & 25.88 \\
Social capital & 51.51 & 100.00 & 80.25 & \pm & 12.10 \\
Natural capital & 0.00 & 80.00 & 47.14 & \pm & 16.87 \\
\hline
\end{tabular}

\section{Livelihood Strategy}

Livelihood strategy in this study was several activity options conducted by the family to obtain income. There were three types of livelihood strategy applied by the family covering agricultural intensification-extensification, livelihood diversification, and migration. Table 3 showed the livelihood strategy applied by most families (79\%) was agricultural intensification-extensification and there was no families undertaking livelihood strategy of migration. Most families utilized the available natural resources to work in agricultural sector and did not migrate because of several reasons. One of the reasons was the poor road access, long distance (it took 3 hours to get to Leuwiliang Market, the central area of the village), and the high operational cost.

The agricultural intensification-extensification strategy of the plantation worker family were farming and breeding. The farming activity was not conducted only by the family who owned paddy field, but also by the family who did not have it and worked as a labor. Commonly, besides farming in paddy field, the family also planted cassava, taro, banana, and guava in the garden or in the yard. The farming result was to be sold and to be consumed by the family. The livestocks owned by the family in common were goat and hen. Like farming, the family who did not have livestock would rise the livestock of other people and in turn they would be paid with the goat kid. Other livelihood sources of the family were seller (3\%), makbeurang service (2\%), cookies seller for celebration event $(3 \%)$, religion teacher $(1 \%)$, mechanic $(1 \%)$, driver $(1 \%)$, and labor $(11 \%)$.

Table 3 Distribution of family by livelihood strategies

\begin{tabular}{lcc}
\hline Livelihood activity & $\mathrm{n}$ & $\%$ \\
\hline Agricultural intensification-extensification & & \\
Farming & 40 & 40.00 \\
Livestock farming & 17 & 17.00 \\
Farming and livestock farming & 21 & 21.00 \\
Total & 79 & 79.00 \\
Livelihood diversification & 5 & 5.00 \\
Farming and other & 3 & 3.00 \\
Livestock farming and other & 13 & 13.00 \\
Other & 21 & 21.00 \\
Total & 0 & 0.00 \\
Migration & & \\
\hline
\end{tabular}




\section{Family Well-Being}

According to indicator of National Population and Family Planning Board, the result showed that one-thirds of the family was categorized as poor family. The result also showed that the average of family income per capita was Rp501.006. Based on poverty line of Statistics Indonesia, one-third of the plantation woker family (33\%) was also categorized as poor.

Table 4 Distribution of family well-being by indicator of National Population and Family Planning Board and poverty line of Statistics Indonesia

\begin{tabular}{|c|c|c|c|c|}
\hline \multirow[t]{2}{*}{ Category } & \multicolumn{2}{|c|}{$\begin{array}{c}\text { NPFPB indicator } \\
\text { (Poor : Pre-P and P-I, Non poor : P-II, P- } \\
\text { III dan P-III Plus) }\end{array}$} & \multicolumn{2}{|c|}{$\begin{array}{c}\text { SI indicator } \\
\text { (Poor: income }<\text { Rp271970 } \\
\text { Non poor: income }>\operatorname{Rp} 271970)\end{array}$} \\
\hline & $\mathrm{n}$ & $\%$ & $\mathrm{n}$ & $\%$ \\
\hline Poor & 32 & 32.00 & 33 & 33.00 \\
\hline Non poor & 68 & 68.00 & 67 & 67.00 \\
\hline Total & 100 & 100.00 & 100 & 100.00 \\
\hline
\end{tabular}

\section{Factors That Influence Objective Well-Being}

The factors that influenced objective well-being of the family in this study was analyzed by the logistic regression analysis. The input variables put into the model were family characteristics, family capital ownership, and livelihood strategy. Table 5 showed that Chi square and Negelkerke R Square score indicated the strong correlation between prediction and classification on the model. This logistic regression model explained the influence on family well-being as many as 55.7 percent while the other 43.3. percent was influenced by other variables which was not analyzed in this study.

Table 5 Logistic regression coefficient of factors that influence objective well-being of the family

\begin{tabular}{lccc}
\hline \multirow{2}{*}{ Variable } & \multicolumn{3}{c}{ Family well-being } \\
& $\mathrm{B}$ & Exp(B) & $\mathrm{Sig}$ \\
\cline { 2 - 4 } Constant & 0.550 & 1.734 & $0.018^{*}$ \\
Husband age (year) & -0.095 & 0.909 & $0.001^{* *}$ \\
Family size (person) & -1.222 & 0.295 & 0.930 \\
Social capital (index) & -0.003 & 0.997 & 0.256 \\
Natural capital (index) & 0.027 & 1.027 & $0.007^{*}$ \\
Physical capital (index) & 0.158 & 1.171 & $0.038^{*}$ \\
Financial capital (index) & 0.037 & 1.038 & 0.736 \\
Human capital (index) & 0.014 & 1.014 & 0.286 \\
Livelihood strategy (0=agricultural intensification- & -1.070 & 0.343 & \\
extensification, 1= livelihood diversification) & & & 81.486 \\
\hline Chi-square & & & \\
Negelkerke $\mathrm{R}^{2}$ & & & \\
\hline Note. $(*)$ significant at $\mathrm{p}<0.05 ;(* *)$ significant at $\mathrm{p}<0.01$ & &
\end{tabular}

\section{Discussion}

This study aimed to examine the livelihood strategy and the well-being level of plantation worker family. The result showed that most families applied agricultural intensification-extensification strategy. This is in line with the study of Pramudita 
(2014) which showed that many families in different area both rural and urban conducted agricultural intensification-extensification strategy.

Agricultural intensification-extensification strategy was mostly undertaken by the family who owned the fields and gardens in which the yield was used for personal consumption or for sale. In line with the study of Eneyew and Bekele (2012), domestic farmers with large tracts of land more likely chose to do agricultural enxtensification compared to the diversification. Agricultural intensification-extensification strategy was also undertaken by the family by increasing the working time such as starting work early at $05.00 \mathrm{AM}$. In addition, families did this strategy by utilizing their yards as a source of food, traditional medicine, herbs, and aesthetics.

Meanwhile, the livelihood diversification strategy was mostly done by the family which had other jobs outside the agricultural sector, such as seller, makbeurang services, cookies seller in special event, religious teacher, and labor. Moreover, the livelihood diversification strategy was conducted by the family who had more than one breadwinner. The study of Eneyew and Bekele (2012) showed a positive effect on the election of livelihood diversification strategy by the family. It means that the more the family members, the more the worker in the family. Conversely, the ownership of livestock affected negatively on the election strategy of livelihood diversification. The fewer the number of livestock owned by the family, the higher the opportunity to seek employment in off-farm and non-farm (Eneyew and Bekele, 2012). Moreover, according to Barret, Reardon, and Webb (2001), education is one very important factor in the (election) livelihood diversification strategy by finding employment in off-farm and non-farm. Education will determine the expertise of a person and affects the amount of salary received.

The results showed that two-thirds of the family was categorized as non-poor according to indicator of NPFPB. This is consistent with the study of Eden (2008) which showed that the well-being of most families were categorized as moderate. Meanwhile, the study of Elmanora, Muflikhati, and Alfiasari (2012) showed that more than half of the family was categorized as poor based on indicators of NPFPB. In contrast, the family in this study mostly had good conditions and decent houses and had met the home standard of floor area of at least $8 \mathrm{~m}^{2}$ per person. Iskandar (2007) revealed that housing and environment can be used as indicators of well-being because the better facilities owned, the more prosperous family will be.

Furthermore, according to poverty line from SI (2013) in Bogor Regency of Rp271.970 per capita per month, more than half of plantation worker family were categorized non poor (above Rp271.970) while nearly one-third of the rest families were categorized poor (below Rp271.970). In comparison, the number of families who were poor based on SI poverty line was not much different with the number of families who were poor based on NPFPB indicator.

The result of logistic regression analysis of family capital and family livelihood strategy showed that the husband age negatively affected on family well-being. The younger the husband, the greater the opportunity for family to get prosperity. This is in line with the study of Elmanora, Muflikhati, and Alfiasari (2012) which showed that the husband age and family income were the factors affecting the family well-being based on NPFPB indicators. These conditions indicated that most families had head of family in productive age. The existence of family member with productive age provided the opportunities for families to increase potency in upgrading their income (Alfiasari, 
2008). Meanwhile, families with larger incomes had higher well-being (Muflikhati et al., 2010).

The family size negatively effected on family well-being based on criteria from NPFPB. It means that a family with fewer number of members was more likely to prosper. Family with fewer number of members were more likely to prosper (Nadiya, 2013). The reason for this is that the fewer number of family members will demand the family to have bigger house compared to small sized family. Besides, it will increase the probability for the family to not being categorized as poor family according to NPFPB indicator. In addition, logistic regression analysis also showed that physical and financial capital positively affected on family well-being. Family with the ownership of physical and financial capital will be more likely to prosper. The study of Iskandar (2007) indicated that the family well-being was affected by the ownership of family capital.

\section{Conclusion and Recommendation}

\section{Conclusion}

The ownership of physical, financial, and natural capitals of plantation worker family was categorized as moderate. Meanwhile, the ownership of human capital was in low level and of family social capital was high-categorized. The livelihood strategies carried out by most of the family was the agricultural intensification-extensification strategy. Based on NPFPB indicator and SI poverty line, more than half of plantation worker families was categorized as prosperous. The factors influencing the family wellbeing were age of the family head, family size, and the ownership of physical and financial capital. Families with a young head-of-family, less number of family member, the and the ownership of physical and financial capital had higher opportunity to be more prosperous compared to families which were not under those condition.

\section{Recommendation}

The results showed that the ownership of family physical and financial capital had an opportunity to increase family well-being. Therefore, the increasing knowledge of saving by the family is needed to encourage the family in having physical and financial capital. It can be carried out by training programs and facilities for running a saving union actively. In addition, various training skills are needed for the families around the tea plantations Cianten because most of them do not have any other special skills except farming. The result showed that the education level of the family was still in a low level and a few children of family graduated from junior high school and then went to work in town as laborers. Based on the field observations, the access of the family for senior high school was very limited. Therefore, further study is expected to see the value of investments in subsidiary and parent perceptions towards education. In addition, further study is also expected to measure subjective well-being of family, by comparing subjective well-being of the husband and wife. 


\section{Reference}

Alfiasari. (2013). Analisis modal sosial dalam pemberdayaan ekonomi keluarga miskin di Kelurahan Kedung Jaya, Kecamatan Tanah Sereal, Kota Bogor [Analysis of social capital in economic empowerment of poor families in Kedung Jaya Village, Tanah Sereal District, Bogor]. Jurnal Ilmu Keluarga dan Konsumen, 1(1), 29-42.

Barrett, C. B., Reardon, T., \& Webb, P. (2001). Non-farm income diversification and household livelihood strategies in rural Africa: Concepts, dynamics, and policy implications. Journal Food Policy, 26, 315-331. doi: 10.1016/S03069192(01)00014-8.

Chambers, R., \& Conway, G. (1991). Sustainable Rural Livelihood: Practical Concepts for 21st Century, IDS Discussion Paper 296: IDS. Institute for Development Studies: Brighton.

Dharmawan, A. H. (2001). Farm Household Livelihood Strategies and Socio Economic Changes in Rural Indonesia. Retrieved from http://repository.ipb.ac.id/handle/123456789/27926.

Dharmawan, A. H. (2006). Sistem Penghidupan dan Nafkah Pedesaan Pandangan Sosiologi Nafkah (Livelihood Sociology) Mazhab Barat dan Mazhab Bogor [Livelihoods Systems of Rural Livelihood Sociology Western views and Bogor views]. Sodality: Jurnal Trandisiplin Sosiologi, Komunikasi, dan Ekologi Manusia, 1(2). Retrieved from http://journal.ipb.ac.id/index.php/sodality/article/view/5932.

Elmanora, Muflikhati, I., \& Alfiasari. (2012). Kesejahteraan keluarga petani kayu manis [Well-being of cinnamon farm families]. Jurnal Ilmu Keluarga dan Konsumen, 5(1). Retrieved from http://journal.ipb.ac.id/index.php/jikk/article/view/6338.

Ellis, F. (1998). Household Strategies and Rural Livelihood Diversification. The Journal of Development Studies, 35(1), 1-38. doi: 10.1080/00220389808422553.

Ellis, F., Kutengule, M., \& Nyasulu, A. (2002). Livelihood and rural poverty reduction in Malawi (LADDER Working Paper No. 17). Retrieved from http://r4d.dfid.gov.uk/PDF/Outputs/Livelihoodsresearch/Ladder-wp17.pdf.

Eneyew, A., \& Bekele, W. (2012). Livelihood Strategies and its determinants in Southern Ethiopia: The Case of Boloso Sore of Wolaita zone. Journal of Social Sciences. Ethiopia University.

Fatwa, N. (2014). Kepadatan, kesesakan, privasi dan kesejahteraan subjektif keluarga di pemukiman marginal Kota Bogor [Density, crowded, privacy, and subjective well-being of marginalized settlement in Bogor] (Undergraduate thesis). Retrieved from http://repository.ipb.ac.id/handle/123456789/71945.

Firdaus. (2008). Hubungan antara tekanan ekonomi, manajemen keuangan, danmekanisme koping, dengan kesejahteraan wanita pemetik teh [The correlation of economic pressure, financial management, and coping mechanism with plantation women worker's family welfare in Malabar Garden, PTPN VIII Bandung, West Java] (Undergraduate thesis). Retrieved from http://repository.ipb.ac.id/handle/123456789/1879.

Grootaert, C. (1999). Social capital, household welfare and poverty in Indonesia (Policy Research Working Papers). doi: 10.1596/1813-9450-2148.

Harianto, M. P. (2013). Tipologi strategi nafkah keluarga petani kopi di Desa Rowosari Kecamatan Sumber Jambe Kabupaten Jember [The typologies of Livelihood Strategies of The Coffee Farmer Households at Rowosari Village Sumber Jambe Sub-District Jember Regency] (Undergraduate thesis). Retrieved from 
http://repository.unej.ac.id/bitstream/handle/123456789/2103/Mei\%20Puji\%20Hari anto\%20-\%20071510201092_1.pdf;sequence=1.

Iskandar, A. (2007). Analisis praktek manajemen sumberdaya keluarga dan dampaknya terhadap kesejahteraan keluarga di Kabupaten dan Kota Bogor [Analysis of family resource management practices and its impact on family well-being in the regency and the city of Bogor]. Jurnal Ilmu Keluarga dan Konsumen, 2(1), 81-98. Retrieved from http://journal.ipb.ac.id/index.php/sodality/article/view/5890.

Masithoh, A. D. (2005). Analisis strategi nafkah rumah tangga petani perkebunan rakyat [Analysis of livelihood strategies of smallholders family] (Unpublished undergraduate thesis). Bogor Agricultural University, Bogor.

Muflikhati, I., Hartoyo, Sumarwan, U., Fahrudin, A., \& Puspitawati, H. (2010). Kondisi sosial ekonomi dan tingkat kesejahteraan keluarga: Kasus di wilayah pesisir Jawa Barat [Socio-economic conditions and the level of family well-being: Cases in coastal areas of West Java]. Jurnal Ilmu Keluarga dan Konsumen, 3(1), 1-10.

Nadiya, A. (2013). Hubungan antara kesejahteraan keluarga dengan kesejahteraan anak pada keluarga petani [Correlation between Family Well-Being and Child Well-Being on Farm Families] (Undergraduate thesis). Retrieved from http://repository.ipb.ac.id/handle/123456789/67379.

National Population and Family Planning Board. (2005). Profil Hasil Pendataan Keluarga [Profile of Family Data Collection]. Jakarta, Indonesia: Author.

Pramudita, N. O. (2014). Strategi nafkah dan tingkat kesejahteraan pada keluarga miskin [Livelihoods strategies and levels of well-being of poor families] (Undergraduate thesis). Retrieved from http://repository.ipb.ac.id/handle/123456789/72049.

Puspitawati, H. (2012). Gender dan Keluarga: Konsep dan Realita di Indonesia [Gender and Family: Concept and Reality in Indonesia]. Bogor, Indonesia: IPB Press.

Saragih, S., Lassa, J., \& Ramli, A. (2007). Kerangka penghidupan berkelanjutan [Sustainable livelihoods framework]. Retrieved from http://www.zef.de/module/register/media/2390_SL-Chapter1.pdf.

Scoones, I. (1998). Sustainable rural livelihood: A framework for analysis (IDS Working Paper 72). Retrieved from http://opendocs.ids.ac.uk/opendocs/bitstream/handle/123456789/3390/Wp72.pdf?se quence $=1$.

Statistics Indonesia. (2011). Jumlah dan Persentase Penduduk Miskin dan Garis Kemiskinan Menurut Kabupaten/Kota Tahun 2011 [Number and Percentage of Poor People and Poverty Line By Regency/City in 2011]. Retrieved from jabar.bps.go.id/subyek/jumlah-dan-persentase-penduduk-miskin-dan-gariskemiskinan-menurut-kabupaten/kota-tahun-2011.

Statistics Indonesia. (2013). Jawa Barat dalam Angka [West Java in Figures]. Jakarta, Indonesia: Author.

Sunarti, E. (2008). A study of plantation women workers, socio economic status, family strength, food consumption, children growth and development. Department of Family and Consumer Sciences, Faculty of Human Ecology, Bogor Agricultural University, Bogor.

Sunarti, E. (2012). Tekanan ekonomi dan kesejahteraan objektif keluarga di perdesaan dan perkotaan [Economic pressures and subjective well-being of families in rural and urban]. Prosiding Seminar Hasil-Hasil PPM IPB. 
Widiyanto, Suwarto, \& Setyowati, R. (2010). Dinamika nafkah keluarga petani pedesaan dengan pendekatan sustainable livelihood approach (SLA) [The dynamics of the family income of rural farmers with sustainable livelihood approach]. Jurnal Agritext. (28), 80-88. Retrieved from http://eprints.uns.ac.id/11094/1/Publikasi_Jurnal_\%2820\%29.pdf.

Widodo, S. (2011). Strategi nafkah berkelanjutan bagi keluarga miskin di daerah pesisir [Sustainable livelihood strategies for poor families in coastal areas]. Makara, Sosial Humaniora, 15(1), 10-20. Retrieved from http://journal.ui.ac.id/index.php/humanities/article/viewFile/890/849.

Yadollahi, M., Paim, L., Othman, M., \& Suandi, T. (2009). Factors affecting family status. European Journal of Scientific Research, 37(1), 94-109. 